\title{
Skæbne og teknik
}

\author{
PÉTER NÁDAS
}

Jeg vil gerne sige nogle velkendte ord.

Nederlag. Tab. Sammenbrud. Fallit. Tilintetgørelse. Fattigdom. Sult. Opfindsomhed. Stank. Håbløshed. Magtesløshed. Sorg. Sygdom. Svaghed. Smerte. Reduktion. Pine. Kulde. Støv. Tungsind. Vemod. Tvivl. Mistro. Fortvivlelse. Fiffighed. Glæde. Forvirring. Resignation. Underkuelse. Glemsel. Fornedrelse. Isolation. Anklage. Selvanklage. Bebrejdelse. Beklagelse. Vrede. Hævn. Selvbedrag. Løgn. Satisfaktion. Afhængighed. Fejhed. Udleverethed. Dumdristighed. Oprør. Fiasko. Uretfærdighed. Rettighedsberøvelse. Fangenskab. Vilkảrlighed. Indskrænkning. Frygt. Angst. Luftmangel. Skam. Blufærdighed. Knaphed. Lidelse.

Og så har jeg ikke engang nævnt nogle mere pinagtige ord. Forhør. Afstraffelse. Tortur. Henrettelse. Og dødsens stilhed.

Jeg vil gerne sige nogle andre velkendte ord.

Overenskomst. Opbygning. Fremskridt. Håb. Udvikling. Beskæftigelse. Udvidelse. Orden. Udbygning. Investering. Refusion. Fortjeneste. Succes. Glæde. Skinsyge. Misundelse. Konkurrence. Bedrag. Omhu. Opmærksomhed. Bestræbelse. Talent. Niveau. Kvalitet. Balance. Duft. Rigelighed. Velfærd. Overskud. Egoisme. Nydelse. Mæthed. Besiddertrang. Vellyst. Proportionalitet. Mådehold. Kritik. Forståelse. Forhærdelse. Skånselsløshed. Ảbenhed. Styrke. Lyssyn. Velgørenhed. Alvor. Vildfarelse. Genstart. Distance. Differentiering. Struktor. Selvstændighed. Sterilitet. Kølighed. Ensomhed. Isolation. Selvbevidsthed.

Og så har jeg ikke engang nævnt nogle væsentlige ord. Kreativitet. Suverænitet. Spontanitet. Frihed.

Ingen mennesker kan karakteriseres med disse ordgrupperinger, eftersom ingen er $\mathrm{i}$ stand til at skille sine fiaskoer fra sine successer, sine lidelser fra sine glæder, sine riederlag fra sine sejre, sin stank fra sin duft, men disse ordgrupperinger er måske alligevel egnet til at karakterisere de livsbetingelser og samfundsorganisationsteknikker, som i de forløbne fyrretyve år har udstukket rammerne omkring vor personlige tilværelse: ikke teorierne og ideologierne, men vort livs realitet.

I den ene gruppe står mennesket, der er udleveret til sin skæbne, i den anden gruppe står mennesket, der organiserer sin skæbne; det ene bestræber sig på at overleve, at udholde det, som det andet prøver at indrette og forme. Det er en meget stor forskel såvel på de personlige erfaringers som på de personlige længslers, målsætningers, adfærdsmønstres og fremgangsmåders plan. Jeg tvivler heller ikke på, at vi i vor fælles tilværelses kommende årtier vil komme til at misforstå hinanden i disse forskelles tegn.

Jeg vil gerne tale om de fænomener, som en græker med min tankegang på den ene side ville kalde forsyn, af en eller anden guds vilje styret række af hændelser (tyche) og på den anden side snilde, håndværksmæssig kunnen, evne, finesse, underfundighed (techne), og som vi i dag ville kalde skæbne og teknik. Mennesket, der står i den ene gruppe, lever sin skæbne uden hverken at kunne forme eller organisere den, følgelig har han heller ingen teknik til det, og mennesket, der står i den anden gruppe, har ganske vist teknikken, men ved $\mathrm{i}$ virkeligheden ikke, hvad han former og organiserer. De prioriterer forskelligt indenfor én og samme dualitet, den ene skuer for langt, den anden for kort, og således har ingen af dem ret gode chancer for at forstå hinanden. Jeg vil ikke sige, at de slet ingen chancer har, for deres sanseapparat fungerer uændret i samme 
dualitets tegn, men deres id og tænkning står i hvert fald i prioriteringernes tegn. Hvilket betyder, at de ikke blot har problemer med at forstå hinanden, men at heller ikke deres personlige liv består af andet end en logisk række af pinlige misforståelser. $\mathrm{Og}$ af dette kan man slutte, at der her ikke blot er tale om kommunikationsforstyrrelser i almindelighed, men snarere om en kommunikationsforstyrrelse, der hidrører fra en konfus selvkundskab og verdensanskuelse. Heller ikke dette opfatter de mere som dualitet, men giver henholdsvis verdensanskuelsen og selvkendskabet fortrinsret.

Et menneske, der er overladt til sin skæbne, opfatter begivenhederne som naturfænomener, han universaliserer letsindigt sin egen situation og opfatter sin virksomhed som tvang, hvorimod et menneske, der organiserer sin skæbne, afgrænser omhyggeligt sit virkefelt, individualiserer sin situation og opfatter begivenhederne som modellerbare gennem overenskomster. Et menneske, der er overladt til sin skæbne, tænker regressivt, han slutter sig til årsag ud fra virkning, søger forklaring $\mathrm{i}$ fortiden og refererer til retfærdigheden, hvorimod et menneske, der organiserer sin skæbne, tænker progressivt, han slutter sig til virkning ud fra årsag, søger acceptable overenskomster i nuet og refererer til loven. Et menneske, der er overladt til sin skæbne, har kun historie, men ingen individuel krønike, og et menneske, der organiserer sin skæbne, har kun en individuel krønike, men ingen historie; det førstnævnte søger helst tilbage $\mathrm{i}$ tiden før den franske revolution, fordi han er nødt til at finde moralsk forsvarlige mønstre til sin overlevelses- og tilpasningstvang, mens det sidstnævnte opfatter hele historien som en individualiseringskrønike og ser helst ikke tilbage i tiden før modernisationen. Det ene erindrer tvangsmæssigt, det andet glemmer tvangsmæssigt. Et menneske, der er overladt til sin skæbne, har følgelig altid en personlig, intim, men ikke individuel sprogbrug, hvorimod et menneske, der former sin egen skæbne, har altid en individuel sprogbrug, men går langt udenom alt, som kan henføres til noget intimt eller personligt; det ene støtter sig snarere til traditionen, det andet til det aktuelle, det ene øser af et magisk og mytisk, det andet af et mytisk og mentalt bevidst- hedsindhold. Det enes talesæt er præget af ubehagelig træghed, ælde og provinsialisme, det andet demonstrerer ikke mindre ubehageligt med sin hurtighed, sin overensstemmelse med tiden og sin viden. Et menneske, der er overladt til sin skæbne, finder sig selv i den kollektive identitet, og et menneske, der former sin skæbne, $\mathrm{i}$ den individuelle identitet.

Deres kommunikationsforstyrrelse er forholdsvis nem at afgrænse, for det er let at indse, hvilke adfærdsmønstre og hvilke sprogbrugsstereotyper, der står bag det ene og det andet menneskes mentalitet. Ligesom vi også forholdsvis let kan forstå, at bulgarerne ryster på hovedet, når de mener ja, og nikker, når de mener nej, eller at englænderne ikke anvender højre, men venstre vigepligt i trafikken. Men kommunikationsforstyrrelsen bliver mere alvorlig af, at der ikke blot ligger de modsætninger, der kan formuleres og afgrænses geografisk ud fra forskellene $\mathrm{i}$ den historiske situation eller $\mathrm{i}$ civilisationsniveauerne, bag forskellene $i$ adfærdsmønstre og sprogbrugsstereotyper, men en konfusion i selvkundskab og verdenssyn, som kendetegner hele den europæiske kultur.

Det er denne sammenhæng, jeg gerne vil demonstrere gennem et simpelt eksempel.

Et menneske stiller, om ikke af andet så af lutter høflighed, et andet menneske spørgsmålet: hvordan har $d u$ det? Spørgsmålet er ganske vist blevet godt slidt ved flittig brug, men mærkværdigvis har det ikke taget skade, for dualiteten mellem godt og ondt står lige bag, det indbefatter nyfigenhed og videbegærlighed, kontrollens og selvkontrollens proces og, svarende til svarets kvalitet, også sandhed og løgn, ærlighed og falskhed, afvisning og medfølelse, formodning og følgeslutning, alt det $\mathrm{i}$ aftryk, som værdidomme bygger på, alt det, som er en forudsætning for selvkundskab og verdenssyn.

Når to mennesker, der er overladt til deres skæbne, mødes, ville svaret: jeg har det godt, forårsage den størst mulige bestyrtelse, for det ville være ensbetydende med, at det ene ikke ønsker at påtage sig skæbnefællesskab med det andet $i$ hele den elendighed, som er vort liv, og derfor, hvis disse mennesker ønsker at være høflige, må de bestræbe sig på at overgå hinanden $\mathrm{i}$ en grundig og detaljeret ud- 
pensling af skæbnens ulidelighed. Og det gør de, også selv om de tilfældigvis skulle befinde sig ganske vel, for den i den elementære hølighed udtrykte kollektive identitet forlanger af dem, at de ikke bebyrder hinanden med deres velbefindende. Af de mennesker, der former deres egen skæbne, forlanger den elementære høflighed lige det modsatte. Det er i begges grundlæggende interesse ikke at bebyrde hinanden med deres ildebefindende, selv om de tilfældigvis skulle have det skidt, for ellers ville de være nødt til at betro en fremmed den intime information, at de har formet deres skæbne dårligt, at de har taget fejl, at de er tabere, og i så fald ville de drage enhver forpligtende ideals funktionsdygtighed i tvivl, hvorpå de mennesker, der former deres egen skæbne, bygger den kollektive identitet. De forstnævnte er derfor nødt til at simulere, mens de sidstnævnte er nødt til at dissimulere.

Og så kan det heller ikke undre nogen, at når et menneske, der er overladt til sin skæbne, møder et menneske, der former sin egen skæbne, forårsager deres svar bestyrtelse hos dem begge. Uvægerligt făr de den opfattelse, at den anden har forbrudt sig mod de mest elementære høflighedsregler, skønt deres simulation, henholdsvis dissimulation relaterer til det samme: skæbnen. Men hverken den ene eller den anden af dem er $i$ stand til at gennemskue, hvorfor de, stillet over for deres skæbne, er tvunget til at simulere, henholdsvis at dissimulere. Det, der for den ene lyder som ubeføjet jammer, fordi han i dualiteten mellem godt og ondt har prioriteret det gode, forekommer den anden som grundløs pral, fordi han i selvsamme dualitet har prioriteret det onde. Og et sådant møde ville forløbe endnu mere pinagtigt, hvis de gav hinanden gode råd. Så ville situationen være lidt den samme, som når en logrende hund møder en kat med halen strittende ubevægelig $i$ vejret. Et sammenstød er uundgåeligt, eftersom det, der hos den ene er udtryk for interesse og venlige hensigter, betyder på den andens sprog mistænkelighed og aggressivitet.

Hidtil har jeg end ikke for enkelhedens skyld anrydet, at den ene skulle være østeuropæer og den anden vesteuropæer. En sådan differentiering ville kun være begrundet, hvis der ikke udelukkende var forskel på deres mentalitet eller på deres identisk rettede udviklingsniveauer, altså alt det, der hører til i den håndværksmæssige kunnens, evnens og erfaringens kreds eller er en direkte konsekvens af den, men jeg havde med sådanne, præcist separerbare grupper af mennesker at gøre, der organiserede og formede deres skæbne efter forskellige metoder, fordi de havde divergerende forestillinger med hensyn til, hvad de organiserede og formede. Men det er desværre ikke det, der er tale om her.

Den ene ved ganske vist, hvad han burde forme og organisere, men netop det mangler han teknikken til, mens den anden har teknikken, men aner til gengæld ikke, hvad han former og organiserer. Og derfor ser jeg ikke dette som en forskel, men snarere som en fra deres væsens karaktertræk hidrørende sammenhæng af anskuelsesdeformiteter, som de skjuler for sig selv og hinanden ved at simulere og dissimulere eller ved de geografiske og politiske begrebers skematiske kontraster.

Jeg kan ikke betragte det som et spil af tilfældigheder, at de deres skæbne formende og organiserende menneskers nationale fællesskaber netop nåede til harmoniseringen af deres geografisk adskilte livs juridiske og økonomiske rammer i samme øjeblik, da de af al magt universaliserende magtsystemer, der gjorde livsbetingelserne for de til deres skæbne udleverede mennesker endegyldigt umulig at forme og organisere, faldt sammen.

Der er måske snarere tale om, at den ideologisk funderede universalisering fremkaldte en ideologisk funderet separatisme, men denne separation prøvede at vogte over de samme, for universelle ansete idéer $i$ en geografisk ramme, som en anden ideologi prøvede at udbrede til alle kontinenter og nationer. Den første gruppe separeredes geografisk, men bevarede i sin politik kravet om de oprindeligt fælles idéers universalitet, og den sidste har mistet universalitetens legitimitet, da den jo måtte separere sig politisk. Det er dog stadig et fælles karaktertræk hos dem begge, at der er en uoverstigelig kløft mellem teori og praksis, ideologi og realitet, om end den ene er blevet mere tilbøjelig til at simulere og den anden til at dissimulere. For det er også forståeligt, at skabelsen af et homogent Europa ud fra en elementær 
mangel på europæisk homogenitet og ved fornægtelse af et kulturelt fællesskab er et ikke mindre umuligt foretagende end at skabe lighed ud fra et manglende broderskab og ved fornægtelse af de mest elementære forudsætninger for personlig frihed.

Jeg må snarere rette mistanken mod en sammenhæng, når de deres skæbne formende og organiserende menneskers nationale fællesskaber netop anså tiden for at være moden til at træde ud af egne nationale rammer og skabe en ny identitet $i$ et juridisk og økonomisk fællesskab, da de til deres skæbne udleverede menneskers såvel politisk som ideologisk separerede fællesskaber allerede havde opbrugt de mentale og økonomiske reserver, der var en følge af praktiseringen af en overnational samfundsorganisering, og derfor heller ikke var i stand til at skabe en ny identitet. Separation kan ikke gennemtrumfes, universaliseringen spillede fallit.

I 1989 ramlede ikke blot det kommunistiske eksperiment, der, byggende på en prioritering af lighed, via en aggressiv ekspansion ville skabe en universal frihed, som den samtidig nægtede individet og følgelig heller ikke sikrede et broderskab mellem individerne, men også det eksperiment fik en gevaldig lækage, der, politisk såvel som geografisk separeret, søgte på bekostning af lighed og broderskab at gennemtrumfe en samfundsorganisationspraksis, som bygger på prioritering af den individuelle frihed. Forskellen er tilsyneladende stor, for det ser jo ud, som om sammenbruddet primært var af økonomisk og lækagen snarere af politisk karakter, og var det sådan, kunne vi i det mindste stadig håbe på den enes livsduelighed.

De sammenbrudte systemer præsenterede dog ikke kun de lækageramte systemer for en slutregning til omgående betaling, der end ikke tilnærmelsesvis var af økonomisk art, men samtidig blev også det åbenbaret, hvorledes de i geografisk separation bevarede, fælles universelle idéer var blevet modificeret; hvorledes frihedsbegrebet blev afløst af begrebet om lighed for loven, hvorledes lighedsbegrebet blev afløst af begrebet om social balance, og hvorledes broderskabsbegrebet var blevet fuldstændig glemt under praktiseringen af den nødvendige sepa- ratisme. De ud af deres nationale rammer brydende fællesskaber bliver netop af deres på reduktion og separation byggende samfundskonstruktions reelle praktisering gjort uegnet til at realisere de idealer, som de har kundgjort gennem fyrretyve år og kundgør den dag i dag, og som den østlige halvkugles folkeslag nu endelig vil realisere, alt imens de falder tilbage i deres egne nationale rammer i samme takt, som de af den vestlige halvkugles folkeslag til separationsbetingelserne tilpassede universelle idealer viser sig ikke-funktionsdygtige.

Alt det, der skete og stadig sker imellem dem, tyder på hele den europæiske kulturs totale bankerot eller $\mathrm{i}$ det mindste på alvorlige funktionsforstyrrelser, og det må frygtes, at det økonomiske sammenbrud på den ene side er uopretteligt, fordi kommunikationsforstyrrelserne på den anden side ikke kan elimineres med politiske midler. Det, der fra Prag, Budapest og i nogen grad fra Berlin ser ud som uoprettelig kulturel fallit, er, set fra Paris eller Frankfurt, blot en overkommelig kommunikationsforstyrrelse. Den, der ved konstatering af kommunikationsforstyrrelser taler om kulturel fallit, tænker på skæbne, og den, der ved konstatering af kulturel fallit taler om kommunikationsforstyrrelser, tænker på teknik.

Skæbne betyder på én gang noget tidsmæssigt og noget tidløst, noget, der sker, og noget, der kan ske, mens teknik i ordets oprindelige betydning betyder det trick, den finesse, den kunst og den håndværksmæssige kunnen, hvorved alt det, som Klotho spinder på sin rok, bliver anvendeligt, alt det, som Lachesis udmåler, bliver inddeleligt, og alt det; som Atropos gør uafvendeligt, bliver alligevel på en eller anden måde forklarligt. Ved konstatering af sammenhængen mellem tyche og techne, ville en græker med en tankegang som min have sagt, at der findes ting $\mathrm{i}$ denne verden, hvis opståen skyldes skæbnen, at disse ting hører naturen (physis) til og er af en beskaffenhed, som den håndværksmæssige kunnen (techne) bragte til live, og som den menneskelige overenskomst (nomos) gjorde anvendelige. Men nomos fik aldrig prioritet frem for naturen, fordi en græker med en tankegang som min ville anse de ting, der hidrører fra naturen, for at være mægtigere, og derfor ville det heller ikke falde ham 
ind at prioritere techne højere end tyche, som vi gør det, og det ville heller ikke falde ham ind at besuæbe sig på at forklare tyche eller at indgå nogle $\mathrm{i}$ hảndværksmæssig kunnen funderede overenskomster uden bevidstheden om naturens magt.

Disse sammenhængende begrebspars funktion har ikke ændret sig i de forløbne flere tusinde år, skønt skæbnens rolle er blevet overtaget af det guddommelige forsyn. Og til trods for at denne sammenhængs indre betoninger har undergået væsentlige ændringer siden det syttende århundrede, tænker vi, uanset om vi taler om kreativitet, som de mennesker, der former og organiserer deres skæbne, eller om opfindsomhed, som de mennesker, der er udleveret til deres skæbne, omkent på den samme tidsmæssighed eller tidløshed, som grækerne må have gjort, når de talte om Nemesis, eller latinerne, når de talte om Fatum. Mennesket former sin situation snart gunstigt og snart ugunstigt, og det lader sig hrerken planlægge eller beregne forlods..Men det er slet ikke den i de fra naturen hidrørende tings billede optrædende skæbne, der står $\mathrm{i}$ vejen for vore spekulationer eller beregninger, og det er heller ikke det guddommelige forsyn, der styrer dem efter sin egen, for et menneske ufattelige indsigt.

Den indre ændring af betoningen kan for så vidt karakteriseres som Nemesis' terrængevinst over for Futum. Takket være Lumiere har vi i omtrent urehundrede år tænkt på en skæbne, som man făr tildelt efter fortjeneste, henholdsvis takket være Bildsng på en skæbne, hvor man må tilstræbe den hæder at forme den selv, også selv om den på forhånd Æ givet. Før den tid måtte vi, takket være det guddommelige forsyn, snarere tænke på en skæbne, som vi havde fảet tildelt, og som var stiv og uforanderhig. Og derfor er det måske lettere at forstå, hvorfor ex menneske, der er udleveret til sin skæbne, må ske tilbage i tiden før den franske revolution, og hrorfor det menneske, der former og organiserer sin skæbne, er uforstående og bliver grebet af panisk angst ved synet af Fatum, som han har byttet om med Nemesis, og hvorfor det til sin skæbne udleverede menneske føler enhver personlig fortjeneste som forfængeligt selvbedrag, når livet nu engang sţres af Fatum. Også det er måske bedre forståeligt, hvorfor den enes længselsbillede er en skæbne, som er lagt i Nemesis' hånd, og hvorfor den andens skrækbillede er en skæbne, som er lagt i Fatums hånd. Denne nuanceforskel har kun eksisteret $i$ fyrretyve år i den europæiske historie. Den kritiske betoningsændrings historie er alt $\mathrm{i}$ alt omtrent trehundrede år gammel. Men disse rent tidsmæssigt afgrænselige forestillingers bevægelse er funderet $i$ et sådant spand af tid på omtrent tusind år, som netop adskiller sig fra andre kulturer på baggrund af disse fælles forestillinger, eller netop prøver at påtvinge andre kulturer $\mathrm{i}$ disse fælles forestillingers tegn.

Der er ingen forskel på et til sin skæbne udleveret vestligt menneskes og et sin egen skæbne formende og organiserende vestligt menneskes tidsopfattelse. Uanset, om han simulerer eller dissimulerer, er hans problem det samme. Allerede ved morgenmaden vil han gerne vide, hvad han skal have til middag, og derfor bestemmes hans forestillinger om tiden af en nysgerrighed, der ikke kan begrænses til nuet. Uanset, om han tror, at det er Fatum, eller han tror, at det er Nemesis, der holder hans skæbne i sin hånd, har han et fremtidsbillede, som han, takket været Fatum eller Nemesis, ikke kan være i besiddelse af.

I øjeblikket har den vestlige kultur et generelt problem og et specielt problem med hensyn til sit fremtidsbillede.

Det generelle problem er, at det ganske vist er lykkedes den til en vis grad at udvide den meget smalle sprække, som en bys, en stats eller sågar et helt, økonomisk og politisk integreret kontinents tyche tillader den menneskelige finesse, fiffighed og håndværksmæssige kunnen, men naturen erklærede sin magt netop ifølge de tekniske evners differentierings- og struktureringsgrad og kvalitet, og derfor betyder differentiering og strukturering ikke, at mennesket kan bestemme over sin egen skæbne, men at han i langt mindre grad er selvbestemmende, end han håbede og regnede med for trehundrede år siden. Han glemte i samme takt naturens magt, som det lykkedes ham at erstatte det guddommelige forsyn med menneskelige overenskomster. 
Og indenfor dette er dens specielle problem, at de til deres skæbner udleverede mennesker hellere tænker på Fatum, når de taler om en brugbar livsteknik, mens de deres skæbner formende og organiserende mennesker hellere tænker på Nemesis, som uddeler skæbnen efter personlig fortjeneste.

Jeg kan ikke sige, om mennesket virkelig bestemmer over sin egen skæbne, og om han i så fald må kæmpe imod de ødelæggende elementer, eller om han ikke bestemmer over sin skæbne, og om han $\mathrm{i}$ så fald højst kan tillade sig visse fiffigheder og finesser over for de ødelæggende elementer. Og jeg kan heller ikke sige, om differentierings- og struktureringsniveauet virkelig er et kriterium for tingenes kvalitet. Den kolde krigs og den fredelige sameksistens' fyrretyve år har kun yderligere uddybet det problem, som den fælles kultur i tre århundreder har slæbt med sig uden at kunne løse. Det er ret så afslørende, at allerede to politiske systemer er brudt sammen i løbet af disse tre hundreder år på grund af manglende kulturel kohærens, og det er ikke mindre afslørende, hvad der er blevet tilbage efter dem.

Den fascistiske utopi er blot et etnisk fællesskabs idé om fremtiden og en altødelæggende metode for alle andre nationer eller etniske grupper. Den kommunistiske utopi er en idé om en fælles fremtid, men ikke en metode. De fra disse to katastrofale idéer separerede demokratiers pragmatiske tankegang er til gengæld ikke en idé om fremtiden, men kun en metode. Taler vi om den kommunikationsforstyrrelse, som i den grad besværliggør de menneskers liv, som former og organiserer deres skæbne, kan vi sige, at her er afskyen for utopier stillet overfor manglen på utopier. At tilbyde manglen på utopier de mennesker, der afskyer enhver form for utopi og alligevel gerne vil vide, hvad de skal have til middag, er et mindst ligeså meningsløst foretagende som at udfylde manglen med en afsky.

Vi kan kun gøre et forsøg på at eliminere kommunikationsforstyrrelserne, hvis vi kontrollerer den i overenskomster funderede metode og vil derfor kun anse de menneskelige overenskomster for acceptable, der sikrer naturens magtposition. Men så længe en meget snæver gruppe stadig ønsker at sik- re sin egen aftensmad ved at true alle andres, vokser ikke blot kommunikationsforstyrrelserne, men også den økologiske krise forværres.

Den økologiske krise og kommunikationsforstyrrelserne tilsammen udgør den totale kulturelle fallit.

På dansk ved Péter Eszterhás 